\title{
Pentingnya Penguatan Ekonomi Masyarakat Pada Masa Pandemi Covid 19 Dalam Meningkatan Manajemen Usaha Masyarakat Pengrajin Kue Berbahan Dasar Jagung
}

\author{
Zuchri Abdussamad ${ }^{1}$, Arifin Tahir ${ }^{2}$ \\ ${ }^{1,2}$ Universitas Negeri Gorontalo, Jl. Jend. Sudirman No.6, Dulalowo Tim., Kota Tengah, \\ Kota Gorontalo, Gorontalo 96128, Indonesia \\ email: zuchriabdussamad@ung.ac.id, arifin tahir@ung.ac.id
}

\begin{abstract}
Abstrak
Permasalahan berantai yang sangat mengganjal pada masa pandemic Corona 19 adalah keterbatasan pengetahuan/keterampilan dan teknologi yang bisa diakses dalam hal teknologi pengolahan berbagai produk tanaman menjadi makanan ringan atau cemilan. pengemasan, pelabelan juga mutu dan hiegine, sehingga belum mampu menembus segmen pasar, ini sangat mempengaruhi ekonomi masyarakat. Permintaan konsumen dapat terpenuhi apabila tingkat produksi tetap kontinyu dan mutu olahan dapat terjaga. Aspek inilah yang masih menjadi permasalahan mendasar oleh kelompok masyarakat tentang teknologi pengembangan produk tanaman jagung atau tumbuhan lainnya. Penyelesaian permasalahan ini dapat ditempuh antara lain melalui pengembangan keterampilan dan manajemen usaha bagi masyarakat yang tergabung pada kelompok Dasawisma di Desa Bulontio Barat Kecamatan Sumalata Timur Gorontalo Utara dalam meningkatkan ekonomi kelompok masyarakat dengan memberikan pendampingan pemberdayaan ilmu dan teknologi tentang pengembangan produk tanaman jagung dan tanaman lainnya supaya lebih baik dan menghasilkan banyak pilihan produk. Berangkat dari permasalahan mitra, maka melalui program pengabdian masyarakat, bersama-sama dengan mahasiswa telah melaksanakan program KKN Tematik dalam bentuk pendampingan, penyuluhan dan pelatihan melalui peningkatan manajemen usaha bagi masyarakat/kelompok Dasawisma di Bulontio Barat Kecamatan Sumalata Timur Gorontalo Utara. Demikian halnya Proses pembelajaran dan pemberdayaan yang diperankan oleh mahasiswa dengan menggunakan metode pendampingan.

Kata kunci Manajemen Usaha, Pandemi Covid 19
\end{abstract}

\begin{abstract}
The chain problem that was very obstructing during the Corona 19 pandemic was the limited knowledge / skills and technology that could be accessed in terms of processing technology for various plant products into snacks or snacks. packaging, labeling as well as quality and hiegine, so that it has not been able to penetrate the market segment, this greatly affects the economy of the community. Consumer demand can be fulfilled if the level of production remains continuous and the quality of processed products can be maintained. This aspect is still a fundamental problem by community groups regarding the technology for developing products of maize or other plants. The solution to this problem can be pursued, among others, through the development of skills and business management for people who are members of the Dasawisma group in Bulontio Barat Village, Sumalata Timur District, North Gorontalo, in improving the economy of community groups by providing empowerment of science and technology on the development of corn and other plant products so better and produce a large selection of products. Departing from partner problems, through community service programs, together with students have implemented the Thematic KKN program in the form of mentoring, counseling and training through improving business management for the community / Dasawisma group in West Bulontio, Sumalata Timur District, North Gorontalo. Likewise, the learning process and empowerment are played by students using the mentoring method.
\end{abstract}

Keywords Business Management, Covid Pandemic 19 
Correspondence author: Zuchri Abdussamad, zuchriabdussamad@ung.ac.id, Gorontalo, and Indonesia

\section{PENDAHULUAN}

Secara umum pemberdayaan masyarakat merupakan salah satu pilar dalam mendukung dan menguatkan pendapatan ekonomi baik secara pribadi, kelompok masyarakat ataupun suatu daerah. Di lapangan, ketidakefektifan penerapan program pemberdayaan ekonomi bagi masyarakat miskin, pada umumnya disebabkan oleh beberapa faktor yaitu: (1) rendahnya tingkat kejujuran dari sebagian pelaksana/pengelola program dan penerima dana bantuan (beneficiaries), (2) lemahnya tingkat koordinasi dan kerjasama, dan (3) Modal sosial/partisipasi masyarakat (dukungan moral) masih bersifat semu. Saefuddin, dkk. (2003)

Dalam upaya meningkatkan kemandirian masyarakat yang memungkinkan masyarakat mampu membangun diri dan lingkungannya berdasarkan potensi, keahlian dan kemauan yang keras dari masyarakat itu sendiri maka diperlukan bentuk-bentuk kegiatan pemberdayaan melalui pelatihan - pelatihan guna mengasah kemampuan setiap masyarakat dalam memulai sektor usaha yang diinginkan.

Upaya pemanfaatan lahan pekarangan dengan tanaman hortikultura sistim vertikultura merupakan langkah yang baik yang disesuaikan dengan kondisi masyarakat pedesaan, baik dari segi ekonomi maupun budaya masyrakatnya. Hortikultura berorientasi pada pengusahaan tanaman disekitar tempat tinggal/pekarangan pada areal terbatas yang menekankan pada jenis tanaman sayuran, buah2an, obat-obatan, bumbubumbuan dan tanaman hias. Kontribusi hortikultura terhadap masyarakat cukup besar di antaranya adalah sebagai sumber pangan dan gizi, pendapatan keluarga, sedangkan bagi lingkungan adalah rasa estetikanya, sekaligus sebagai penyangga kelestarian alam (Ashari Sumeru, 2006).

Sektor Pertanian merupakan sektor yang memegang peranan penting di Indonesia dalam mensejahterakan kehidupan penduduk Indonesia karena sebagian besar penduduknya hidup dari hasil bertani. 
Berawal dari Sektor Pertanian sumber pangan dihasilkan, yang merupakan kebutuhan mendasar masyarakat. Perekonomian di Kabupaten Gorontalo Utara ditopang oleh Sektor Pertanian, Perkebunan, Peternakan, Perikanan, Pariwisata, Tanaman Pangan dan Holtikultura, Kehutanan dan Pertambangan yang di tunjang Infrastruktur Pelabuhan yang menghubungkan perdagangan antar Pulau dan antar Negara.

Desa Bulontio Barat adalah desa yang berada di Kecamatan Sumalata Kabupaten Gorontalo Utara. Desa ini dibentuk pada tahun 2011 yang akan menjadi lokasi kegiatan KKN Tematik tahun 2020, memiliki sumberdaya pertanian yang produktif umumnya dimanfaatkan untuk usaha tani jagung, kacang tanah, sayuran (cabe, terong, kacang panjang, ketimun, tomat), buah (popaya, pisang, nangka, semangka),

Dalam kegiatan pengabdian masyarakat ini fokus kegiatan yang dipilih adalah "Penguatan ekonomi masyarakat pada masa pandemic Covid 19 masyarakat pengrajin kue berbahan dasar jagung di Desa Bulontio Barat". Bidang ini bersesuaian dengan aktivitas kelompok usaha yang ada di Desa Bulontio Barat. Pengrajin kue di desa ini adalah pengrajin kue basah yang terdiri dari ibu-ibu rumah tangga, para gadis desa yang hobi terhadap pembuatan kue. Usaha yang telah lama dilaksananakan sebagai penopang ekonomi keluarga, selanjutnya dipasarkan secara lokal tidak jauh dari lokasi desa ini. Dalam menjalankan usaha produksi kue basah berbahan dasar jagung di lokasi ini belum dilakukan dengan baik Produk kue basah berbahan dasar jagung yang selama ini dihasilkan belum dilaksanakan sesuai dengan manajemen pengelolaan usaha, dan juga produknya belum memenuhi standar pasar yang dibutuhkan konsumen. Bentuk kegiatan yang dilakukan adalah peningkatan kapasitas manajemen pengelolaan usaha kecil untuk memperbaiki mutu produk yang dihasilkan, sehingga dapat memenuhi kebutuhan pasar.

Melalui program KKN-Tematik panitia pelaksana telah melakukan transfer ilmu dan teknologi kepada masyarakat pengguna melalui keterlibatan mahasiswa secara langsung. Mahasiswa sejumlah 31 orang hidup berdampingan dengan penduduk selama 45 hari secara bersama melakukan kegiatan praktek dalam rangka penyelesaian masalah yang 
dihadapi selama ini. Transfer ilmu dan teknologi tersebut telah melibatkan staf dosen yang kompeten, mahasiswa, masyarakat pengrajin kue basah berbahan dasar jagung.

Maksud pelaksanaan pada pengabdian masyarakat melalui KKN Tematik Tahun 2020 ini yakni bersama-sama dengan mahasiswa melaksanakan program KKN dalam bentuk penyuluhan dan pelatihan pada masa Pandemi virus Corona 19 melalui peningkatan manajemen usaha bagi masyarakat/kelompok Dasawisma Desa Bulontio Barat Kecamatan Sumalata Kabupaten Gorontalo Utara. Demikian halnya Proses pembelajaran dan pemberdayaan yang diperankan oleh mahasiswa dilakukan menggunakan metode pendampingan.

Target dalam program pengabdian ini adalah masyarakat pengrajin kue basah yang berjumlah 20 orang sesuai data awal, namum sebagian pengrajin ini tidak aktif karena faktor keluarga, sehingga pengrajin yang dijadikan sebagai pusat pembelajaran hanya berjumlah 15 pengrajin yang tersebar pada 3 Dusun yakni Dusun Pante, Suka Maju, dan Dusun Tengah.

\section{Tabel 1 Kelompok sasaran, potensi dan permasalahannya}

\begin{tabular}{|c|c|c|}
\hline Kelompok Sasaran & Potensi & Permasalahan \\
\hline $\begin{array}{l}\text { Masyarakat Ibu-ibu } \\
\text { yang tergabung dalam } \\
\text { kelompok Dasawisma } \\
\text { Desa Bulontio Barat } \\
\text { Kecamatan Sumalata } \\
\text { Kabupaten Gorontalo } \\
\text { Utara }\end{array}$ & $\begin{array}{l}\text { - Adanya prakarsa } \\
\text { masyarakat untuk } \\
\text { mengolah hasil lahan } \\
\text { Jagung menjadi produk } \\
\text { makanan ringan } \\
\\
\text { - Jagung yang menjadi } \\
\text { bahan baku kue bisa di } \\
\text { diversifikasi }\end{array}$ & $\begin{array}{l}\text { - Keterbatasan pengetahuan } \\
\text { dan ketrampilan dalam } \\
\text { mengolah produk tanaman } \\
\text { jagung menjadi makanan } \\
\text { ringan yang disukai } \\
\text { masyarakat } \\
\text { - Upaya pengolahan menjadi } \\
\text { produk pangan masih } \\
\text { menemui kendala teknis, baik } \\
\text { dari segi mutu, dan } \\
\text { kemampuan diversifikasi } \\
\text { produk. }\end{array}$ \\
\hline $\begin{array}{l}\text { Kelompok } \\
\text { Dasawisma Desa } \\
\text { Bulontio Barat } \\
\text { Kecamatan Sumalata } \\
\text { Kabupaten Gorontalo } \\
\text { Utara }\end{array}$ & $\begin{array}{l}\text { Adanya kepedulian } \\
\text { masyarakat pengrajin } \\
\text { kelompok Dasawisma } \\
\text { Desa Bulontio Barat } \\
\text { Kecamatan Sumalata } \\
\text { untuk selalu meningkat } \\
\text { kan mutu dan keamanan } \\
\text { makanan yang } \\
\text { menggunakan bahan } \\
\text { baku jagung }\end{array}$ & $\begin{array}{l}\text { - Proses produksi } \\
\text { (pengolahan, memasak) yang } \\
\text { masih boros } \\
\text { - Desain bentuk, kemasan } \\
\text { masih sangat tradisional } \\
\text { - Pemasarana hasil yang } \\
\text { kurang lancer dan kurang } \\
\text { menguntungkan }\end{array}$ \\
\hline Kelompok Dasawisma & Adanya keterbukaan & - Pengetahuan masyarakat \\
\hline
\end{tabular}




\begin{tabular}{|c|c|c|}
\hline $\begin{array}{l}\text { Desa Bulontio Barat } \\
\text { Kecamatan Sumalata } \\
\text { Kabupaten Gorontalo } \\
\text { Utara }\end{array}$ & $\begin{array}{l}\text { masyarakat Desa } \\
\text { Bulontio Barat } \\
\text { Kecamatan Sumalata } \\
\text { lebih khusus ibu-ibu yang } \\
\text { tergabung pada } \\
\text { kelompok Dasawisma } \\
\text { atas kesulitan yang } \\
\text { dihadapi dan terus } \\
\text { mencari solusi untuk bisa } \\
\text { terterima oleh konsumen }\end{array}$ & $\begin{array}{l}\text { yang tergabung dalam } \\
\text { kelompok Dasawisma } \\
\text { terhadap penggunaan } \\
\text { Teknolgi atas proses } \\
\text { pengolahan, pencetakan, } \\
\text { model produk, serta kemasan } \\
\text { produk } \\
\text { - Keterbatasan pengetahuan } \\
\text { tentang sanitasi, pengolahan } \\
\text { untuk mengha silkan produk } \\
\text { yang higienis }\end{array}$ \\
\hline
\end{tabular}

Secara umum target capaian yakni terlaksanannya program pengabdian kepada masyarakat berbasis potensi daerah dan penanganan Stunting dan Pandemi Covid 19. Secara khusus Indikator target dan luaran dari kegiatan KKN Tematik Tahun 2020 ini antara lain :

1. Peningkatan pengetahuan masyarakat yang tergabung pada kelompok Dasawisma tentang metode pengolahan tanaman jagung dan tanaman lainnya yang dijadikan sebagai bahan baku makanan ringan.

2. Meningkatnya olahan penganan makanan yang bahan baku jagung menjadi produk lain yang memberi nilai tambah baik dari segi produksi maupun dari segi ekonomi dengan memanfaatkan konsep manajemen usaha

3. Meningkatnya mutu dan higenie produk dan terterima dipasaran dengan memberikan pemahaman seperti menggunakan $\mathrm{K} 3$, perbaikan olahan, perbaikan tempat produksi yang lebih baik dan mengadakan alat saniter.

4. Terciptanya kemasan dan pelabelan yang menarik secara estetika dengan pemenuhan kemasan plastik HDFE dan karton, dan label, Vacum sealer untuk alat pengemas, baskom stainless, wajan.

5. Meningkatnya daya beli konsumen karena sudah mengalami perbaikan dan pengolahan yang menarik.

6. Tertatanya manajemen dan dihasilkannya strategi pemasaran yang menunjang keberlanjutan program dilakukan secara kontiyu untuk meningkatkan pemberdayaan ekonomi lokal masyarakat di Desa Bulontio Barat Kecamatan Sumalata Kabupaten Gorontalo Utara. 
7. Banyaknya orderan atau pesanan pasar yang menyerap hasil produk masyarakat/kelompok Dasawisma Bulontio Barat Kecamatan Sumalata Kabupaten Gorontalo Utara

8. Meningkatnya volume penjualan produk.

9. Luaran dari program ini adalah adanya teknologi proses pengolahan dan strategi pemasaran yang dihasilkan dalam pemanfaatan produk dengaj menggunakan bahan baku tanaan jagung dan tanaman lainnya sebagai wujud pemberdayaan secara massif dan meningkatkan basis ekonomi lokal masyarakat yang berkelanjutan melalui program pengembangan keterampilan dan manajemen usaha

Sedangkan hasil tema dalam jangka panjang program KKN Tematik UNG Tahun 2020 ini adalah keberdayaan masyarakat yakni melalui sentuhan ilmu dan teknologi melalui peningkatan keterampilan dan manajemen usaha masyarakat yang tergabung dalam kelompok Dasawisma di desa Bulontio Barat Kabupaten Gorontalo Utara pada masa pandemic virus Corona 19 dalam menggerakkan sektor usaha/ekonomi masyarakat untuk peningkatan income perkapita, peningkatan indeks pembangunan manusia sehingga tercapai dalam pemenuhan bahan dasar (kebutuhan primer), peningkatan pengetahuan dan keterampilan penduduk desa Bulontio Barat Kabupaten Gorontalo Utara dan indeks pembangunan gender pada aspek partisipasi penduduk desa baik pria maupun wanita.

\section{METODE}

Bidang kegiatan yang dipilih adalah pembinaan kelompok masyarakat pengrajin kue berbahan dasar jagung di Desa Bulonrtio Barat Kecamatan Sumalata Kabupaten Gorontalo Utara. Menggunakan metode dalam bentuk pendekatan pendampingan, penyuluhan dan pelatihan penerapan mutu dan pemasaran hasil produksi. 


\section{Tabel 2 Tahapan dan Kegiatan Pengabdian Mahasiswa selama kegiatan KKN-Tematik Tahun 2020 di Desa Bulontio Barat}

\begin{tabular}{|c|c|c|}
\hline No & $\begin{array}{c}\text { Tahapan } \\
\text { Persiapan dan Pembekalan }\end{array}$ & Kegiatan \\
\hline & $\begin{array}{l}\text { Mekanisme pelaksanaan } \\
\text { kegiatan KKN - Tematik } \\
\text { UNG }\end{array}$ & $\begin{array}{l}\text { - Survai calon lokasi KKN Tematik } \\
\text { - Penyusunan dan pengusulan proposal KKN } \\
\text { Tematik ke LPPM UNG } \\
\text { - Perekrutan Mahasiswa peserta KKN-Tematik } \\
\text { - Pembekalan (coaching) dan pengasuransian } \\
\text { mahasiswa } \\
\text { - Pengambilan perlengkapan Mahasiswa } \\
\text { peserta KKN-Tematik } \\
\text { - Pelepasan Mahasiswa peserta KKN-Tematik } \\
\text { - Pengantaran Mahasiswa peserta KKN- } \\
\text { Tematik ke lokasi } \\
\text { - Penyerahan Mahasiswa peserta KKN-Tematik } \\
\text { oleh panitia ke penanggung jawab lokasi } \\
\text { - Monitoring dan evaluasi pertengahan periode } \\
\text { KKN-Tematik } \\
\text { - Monitoring dan Evaluasi akhir periode KKN- } \\
\text { Tematik Mahasiswa peserta KKN-Tematik }\end{array}$ \\
\hline & $\begin{array}{l}\text { Materi pembekalan yang } \\
\text { diberikan kepada } \\
\text { Mahasiswa peserta KKS- } \\
\text { Pengabdian }\end{array}$ & $\begin{array}{l}\text { - Fungsi mahasiswa dalam KKN-Tematik UNG } \\
\text { Tahun } 2020 \text { oleh LPPM UNG } \\
\text { - Penyampaian Tatib peserta KKN Tematik } \\
\text { selama di lokasi } \\
\text { - Penyampaian materi manajemen usaha pada } \\
\text { era Pandemic Corona } 19 \text { oleh dosen dan } \\
\text { praktisi } \\
\text { - Pelatihan Penyusunan Bisnis Plan bersama- } \\
\text { sama dengan mahasiswa KKN Tematik } \\
\text { - Penyampaian tehnik pengolahan dan teknik } \\
\text { kemasan makanan ringan bahan baku jagung } \\
\text { dan tanaman lainnya oleh dosen dan praktisi } \\
\text { - Simulasi pembuatan makanan ringan dengan } \\
\text { bahan baku jagung dan tumbuhan lainnya } \\
\text { yang diambil dari tanaman yang ada } \\
\text { dihalaman ibu-ibu yang tergabung dalam } \\
\text { kelompok dasawisma oleh dosen dan } \\
\text { mahaiswa peserta KKN Tematik }\end{array}$ \\
\hline
\end{tabular}

Awal kegiatan program KKN-Tematik dimulai koordinasi dengan kepala desa yang mewilayahi lokasi tersebut, pertemuan dengan masyarakat pengrajin kue dan pembicaraan awal dengan pemerintah desa Bulontio Barat. Koordinasi tersebut menghasilkan data-data yang sebagian telah dituangkan dalam proposal.

Sedangkan kegiatan berupa perencanaan adalah koordinasi dengan Lembaga Penelitian dan Pengabdian Masyarakat UNG untuk melakukan perekrutan mahasiswa yang memiliki latar belakang keilmuan yang bersesuaian dengan bidang kerja kelompok pengrajin kue berbahan dasar jagung. Perekrutan mahasiswa dilanjutkan dengan pembekalan di 
kampus menyangkut materi dan teknik sosialisasi dimasyarakat serta penyiapan perlengkapan pendukung selama berada di lokasi KKNTematik. Pemberian materi disampaikan dalam ruang pembekalan. Materi disampaikan oleh pakar terkait bidang pembinaan di masyarakat berikut simulasi teknik penyampaiannya kepada warga. Metode dan jadwal kegiatan mahasiswa selama berada dilokasi juga disampaikan oleh panitia dalam pembekalan.
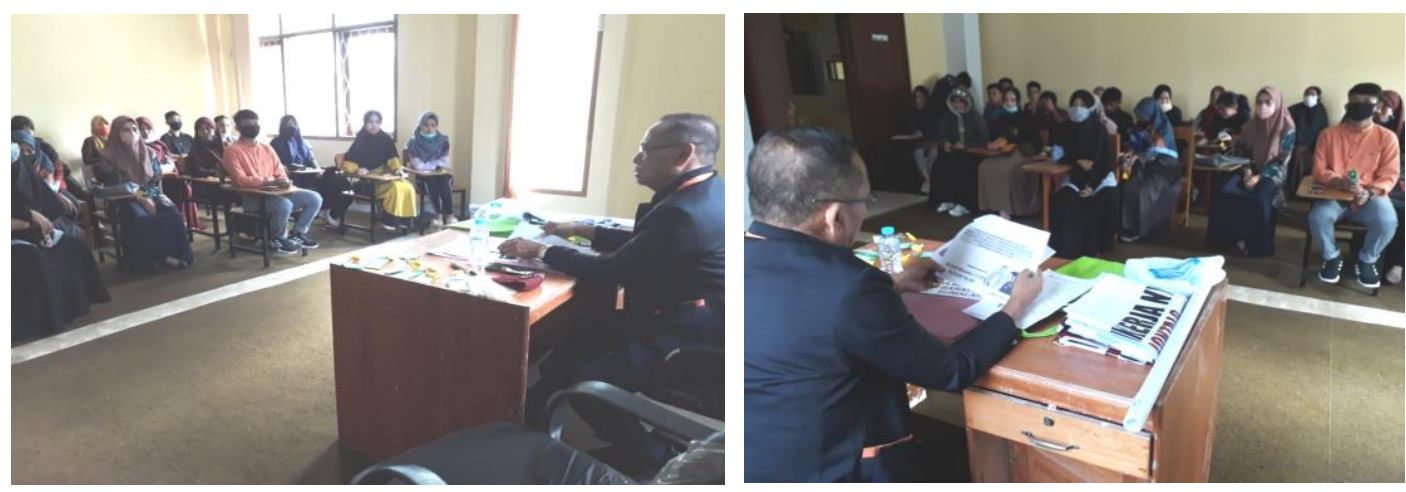

Kegiatan Pembekalan

Penyiapan sarana akomodasi dan asuransi mahasiswa sejumlah 31 orang dilakukan sebelum pemberangkatan ke lokasi Selanjutnya serah terima mahasiswa KKN-Tematik ke pejabat setempat (Kades Bulontio Barat) sebagai tanda resmi kegiatan KKN-Tematik dimulai. Sosialisasi mahasiswa di lokasi dibantu oleh aparat desa dan unsur pemuda/karang taruna. Aktivitas mahasiswa dibagi sedemikian rupa pada segmen kegiatan pengrajin kue berbahan dasar jagung.

Selanjutnya serah terima mahasiswa KKN-Tematik ke pejabat setempat sebagai tanda resmi kegiatan KKN-Tematik dimulai. Sosialisasi mahasiswa di lokasi akan dibantu oleh aparat desa dan unsur pemuda/ karang taruna. Aktifitas mahasiswa dibagi sedemikian rupa pada segmen kegiatan masyarakat pengrajin kue.

Pekerjaan yang dilakukan oleh mahasiswa dan dihitung dalam volume 144 Jam Kerja Efektif Mahasiswa (JKEM) dalam sebulan. Ratarata jam kerja efektif mahasiswa (JKEM) per hari adalah 4,8 sebagai acuan. Uraian Tabel 3. dalam bentuk program dan jumlah mahasiswa pelaksanaanya adalah: 
Tabel 3 Uraian Pekerjaan, Program dan Volumenya dalam waktu 45 hari kerja, 2 bulan

\begin{tabular}{|c|c|c|c|c|}
\hline No & Nama Pekerjaan & Program & Volume & Keterangan \\
\hline 1 & $\begin{array}{l}\text { Pendampingan, pembelajaran di } \\
\text { kelompok dasawisma }\end{array}$ & Produksi & 864 & 7 orang \\
\hline 2 & $\begin{array}{l}\text { Pengolahan kue berbahan dasar } \\
\text { jagung dengan produk lain tersanitasi } \\
\text { dan identifikasi masalah mutu, } \\
\text { hiegene }\end{array}$ & Produksi & 1296 & 9 Orang \\
\hline 3 & $\begin{array}{l}\text { Praktek pengemasan, pelabelan dan } \\
\text { masa simpan }\end{array}$ & $\begin{array}{c}\text { Pengemasan } \\
\& \\
\text { penyimpanan }\end{array}$ & 720 & 5 orang \\
\hline 4 & $\begin{array}{l}\text { Praktek pemasaran produk olahan } \\
\text { berbahan baku jagung }\end{array}$ & Pemasaran & 1440 & 10 orang \\
\hline \multicolumn{3}{|c|}{ Total Volume Kegiatan } & 4320 & 31 orang \\
\hline
\end{tabular}

Langkah-langkah yang dilaksanakan adalah program penyuluhan manajemen usaha, program pemberdayaan pengetahuan dan ketrampilan bagi pengrajin kue tradisional, teknik kemasan serta program pemasaran. Program lain berupa bantuan pengadaan peralatan memasak (kompor gas) dan program pendampingan.

Evaluasi program dilakukan tiap bulan dengan menganalisa datadata input komoditas dan output produk serta tingkat serapan pasar. Evaluasi juga akan dilakukan pada kontribusi bantuan peralatan pengolahan dalam mendukung kelancaran proses produksi. Evaluasi secara khusus dilakukan terhadap mahasiswa baik individu maupun kelompok dalam melakukan aktifitasnya selama ini.

\section{HASIL DAN PEMBAHASAN}

Kegiatan ini menitikberatkan pada penguatan ekonomi masyarakat melalui peningkatan manajemen usaha masyarakat pengrajin kue berbahan dasar jagung Oleh sebab itu kegiatan ini di beri tema "Penguatan Ekonomi Masyarakat pada masa Pandemic Cocid 19 melalui Peningkatan Manajeen Usaha Masyarakat PengrajnKue Berbahan Dasar Jagung di Desa Bulontio Barat Kecamatan Sumalata Kabupaten Gorontalo Utara

Ada 31 orang mahasiswa dari beberapa program studi di lingkungan UNG melalui Program KKN-Tematik telah melakukan kegiatan pembelajaran dan pemberdayaan bagi masyarakat pengrajin kue 
berbahan dasar jagung. Usaha ini banyak dilakukan oleh ibu-ibu rumah tangga dan para gadis remaja yang ada di Desa Bulontio Barat yang kemudian dilakukan suatu promosi dan pemasaran ke berbagai lapisan konsumen yang biasanya sudah memesan terlebih dahulu ataupun ke pasar dan toko-toko terdekat. Usaha pembuatan kue basah berbahan dasar jagung ini sangat potensial dan prospek pengembangannya sangat bermanfaat untuk meningkatkan pendapatan usaha pembuatan kue itu sendiri di era pandemic Virus corona. Sangat disayangkan jika permintaan pasar akan produksi kue berbahan dasar jagung ini harus dipenuhi dari luar daerah hanya karena persoalan mutu produk komentar Faizal Tuta Koordinator Desa (kordes).

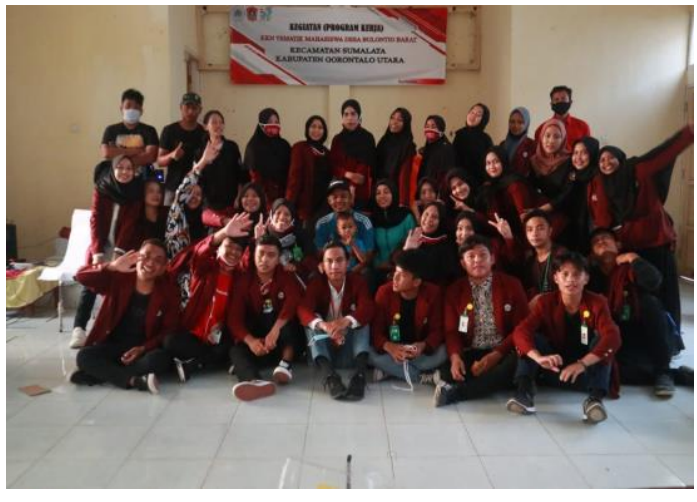

Gambar 1 Peserta KKN Tematik

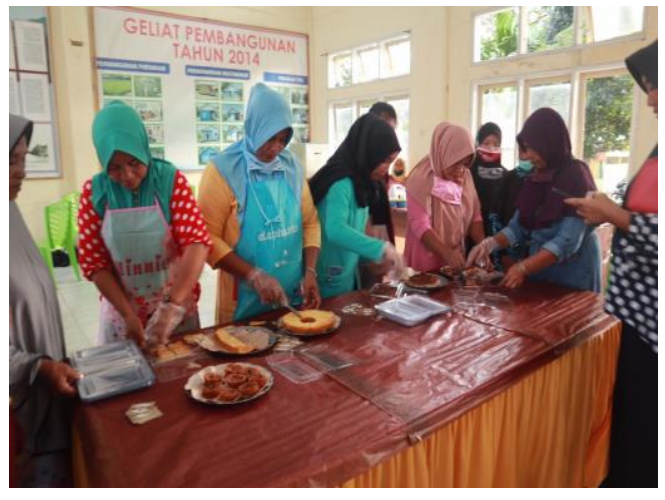

Gambar 2 Kelompok Dasawisma

Dalam kegiatan pengabdian masyarakat ini fokus kegiatan yang dipilih adalah peningkatan kapasitas manajemen dalam meningkatkan mutu usaha yang dilakukan oleh ibu-ibu yang tergabung dalam kelompok Dasawisma Desa Bulontio Barat Kecamatan Sumalata Kabupaten Gorontalo Utara. Bentuk kegiatan yang dilakukan adalah peningkatan manajemen usaha bagi masyarakat yang tergabung pada Dasawisma Desa Desa Bulontio Barat Kecamatan Sumalata Kabupaten Gorontalo Utara pada masa pandemic Covid 19.

Bentuk program yang dilaksanakan oleh peserta KKN-Tematik UNG adalah pelatihan manajemen usaha (Bisnis Plan) pendampingan untuk peningkatan ketrampilan dalam hal produksi dan pengemasan, serta pemasaran. Program lain berupa bantuan teknologi. Metode yang digunakan dalam melakukan pemberdayaan kelompok sasaran adalah teknik pembelajaran kelompok disertai praktek, teknik pembuatan 
kemasan dan pelabelan serta penentuan masa simpan produk (kadaluarsa), teknik pengolahan produk tersanitasi dan teknik pemasaran. Pembelajaran disertai praktek akan dilakukan oleh mahasiswa bersamasama dengan kelompok sasaran.

Berdasarkan kegiatan serta sasaran kegiatan tersebut, maka dapat diidentifikasi bahwa kegiatan ini memerlukan tenaga yang memiliki keahlian diantaranya, tenaga ahli di bidang Manajemen Usaha, Pengolahan Kue Basah, bidang kemasan dan marketing.

Susunan tim ini terdiri dari ketua tim (Dr. Zuchri Abdussamad, S.I.K., M.Si) yang memiliki komptensi pada bidang Manajemen Pelayanan Publik dan Manajemen Bisnis. Berpengalaman sebagai instuktur produktivitas kerja, narasumber kegiatan pemberdayaan UMKM tenant di tingkat Provinsi Gorontalo. Melaksanakan kegiatan pelatihan-pelatihan AMT (achievement motivations trainning) bagi pelaku ekonomi di tingkat kabupaten/kota Gorontalo. (Prof Dr Arifin Tahir, M.Si) sebagai anggota dan DPL Guru Besar tetap UNG yang memiliki kompetensi di bidang Kebijakan Publik.

Prinsip utama dalam menjalankan proses pengabdian ini tim pendamping berpegang pada sebuah pernyataan kunci dari Mao Tse Tung sebagai berikut: "Perhatikan sungguh-sungguh gagasan yang datang dari rakyat, yang masih terpenggal dan belum sistematis. Pelajari gagasan tersebut bersama mereka, sehingga menjadi gagasan yang lebih sistematis. Menyatulah dengan rakyat. Kaji dan jelaskan kembali gagasan yang datang dari mereka itu, sehingga mereka benar-benar paham bahwa gagasan itu milik mereka. Terjemahkan gagasan tersebut menjadi aksi, dan uji kebenaran gagasan tadi melalui aksi. Begitu seterusnya diulangulang secara ajeg, agar gagasan tersebut menjadi lebih benar, lebih penting dan lebih bernilai sepanjang masa" Demikian itulah membangun ILMU PENGETAHUAN RAKYAT" (Abdullah Faishal; 2008)

Dalam jangka panjang program KKN-Tematik ini adalah peningkatan keberdayaan masyarakat melalui peningkatan income perkapita akibat sentuhan pada sektor usaha/ekonomi, peningkatan indeks pembangunan manusia mengingat sentuhan peningkatan pengetahuan dan keterampilan 
masyarakat di Desa Bulontio Barat pada aspek partisipasi penduduk baik pria maupun wanita.

Adapun hasil capaian program KKN-Tematik yakni antara lain:

1. Produk Kegiatan KKN-Tematik

Indikator capaian produk Program KKN-Tematik yang dituju adalah :

$\checkmark$ Peningkatan partisipasi dan kinerja produksi pada tingkat masyarakat pengrajin kue berbahan dasar jagung

$\checkmark$ Variasi rasa yang baik pada lingkup pengolahan, pembungkusan dan pemasaran.

\section{Hasil Tema KKN-Tematik}

Hasil tema dalam jangka panjang program $\mathrm{KKN}$ - Tematik pada masa pandemic Virus Corona ini adalah peningkatan keberdayaan masyarakat melalui peningkatan income perkapita akibat sentuhan pada sektor usaha I ekonomi, peningkatan indeks pembangunan manusia mengingat sentuhan peningkatan pengetahuan dan keterampilan masyarakat di desa pada aspek partisipasi penduduk.

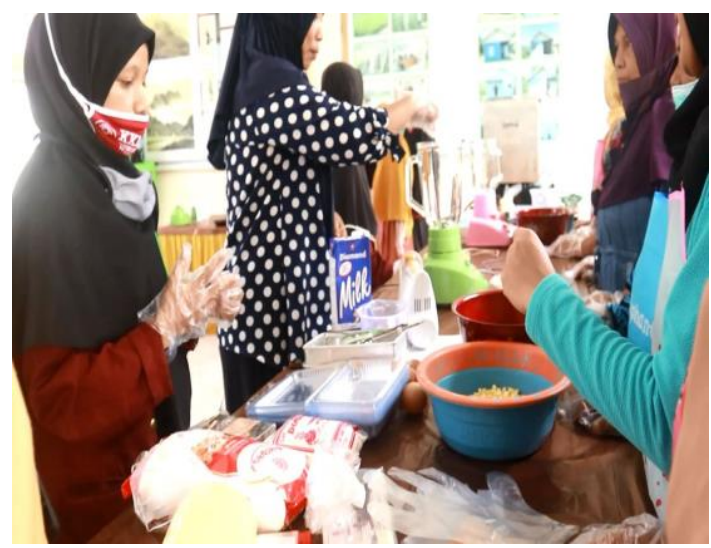

Gambar 3 Kegiatan Praktek

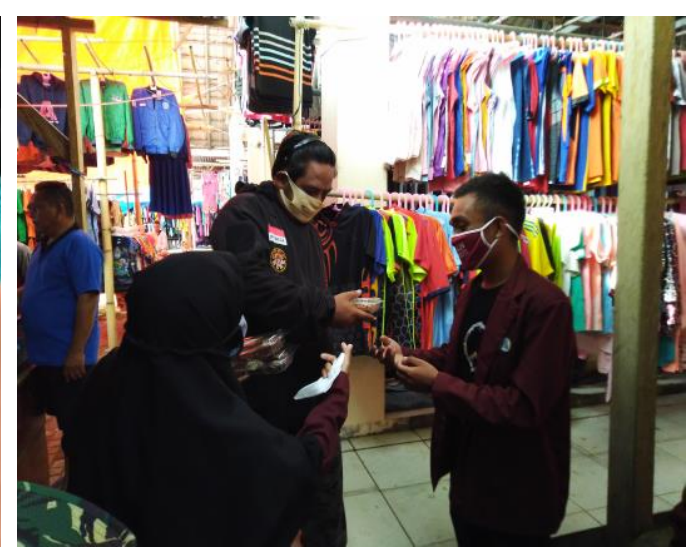

Gambar 4 Kegiatan Pemasaran

Keberlanjutan program ditentukan oleh pola kinerja mahasiswa pada saat mereka melaksanakan kegiatan KKN-Tematik. Alhamdulilah berdasarkan monitoring yang dilakukan oleh pihak internal rata-rata masyarakat pengrajin kue tradisional berbahan dasar jagung ini sangat mengharapkan program tindak lanjut, karena mahasiswa yang telah disebar pada tiga dusun masyarakatnya sangat mengharapkan program pendampingan atau dalam bentuk kegiatan pelatihan dalam rangka 
peningkatan produk komoditas kue basah berbahan dasar jagung pada era pandemic Covid 19 serta merangsang pangsa pasar sehingga program selesai diperoleh pemetaan pasar bagi produk yang dihasilkan sehingga ada penyebaran kue berbahan dasar jagung ini di kabupaten/kota dan wilayah sekitar Gorontalo.

Dalam usaha meningkatkan produksi, menurut Dosen Pembimbing Lapangan Bapak Prof Dr Arifin Tahir, M.Si selain harus mempunyai kreatifitas perlu adanya perbaikan alat produksi dan prosesnya secara intensif dan profesional baik mulai bahan adonan, proses pembuatan adonan hingga barang siap dipasarkan. Dimana ketiga hal ini merupakan mata rantai yang saling berhubungan, namun bisa berdiri sendiri apabila diusahakan. Disamping itu aspek permodalan juga sangatlah penting dalam menunjang usaha pembuatan kue basah berbag=han dasar jagung ini. Dalam rangka pengabdian kepada masyarakat tim KKN Tematik bersama mahasiswa telah memberikan motivasi melalui penanaman jiwa wirausaha, pembinaan, pendampingan dan pelatihan-pelatihan dalam memproduksi kue basah sehingga usaha tersebut dapat ditingkatkan kearah pengembangan yang lebih baik, walaupun waktu yang digunakan hanya 45 hari kerja.

Dalam sambutannya Kepala Desa Bulontio Barat Bapak Rafiq S Madjham, S.AP sangat mensupport dan mengucapkan banyak terima kasih atas kegiatan yang telah dilakukan oleh civitas akademika UNG melalui dharma Pengabdian dalam rangka meningkatkan wirausaha pengrajin kue berbahan dasar jagung yang ada di Desa Bulontio Barat Kecamatan Sumalata Kabupaten Gorontalo Utara dan berharap semoga kepada pengrajin ini bisa menambah ketekunan pengrajin dalam menggeluti peluang usaha di desa dan pada tahap berikutnya UNG akan datang untuk keberlanjutan program pemberdayaan masyarakat melalui Program pemberdayaan lainnya.

\section{KESIMPULAN}

$\begin{array}{ccccc}\text { Semua } & \text { kegiatan berjalan dengan baik dan lancer. Selain itu } \\ \text { masyarakat } & \text { Desa sangat terbuka dan mendukung penuh }\end{array}$


pelaksanaan program yang diharapkan mampu meningkatan kesadaran terhadap masalah dalam meningkatan manajemen usaha.

\section{UCAPAN TERIMA KASIH}

Terima kasih kepada Lembaga Penelitian dan Pengabdian pada Masyarakat (LPPM), Universitas Negeri Gorontalo atas dukungan Dana Pengabdian PNBP 2020.

\section{Daftar Pustaka}

Saefuddin, Asep dkk. (Tim Crescent). 2003. Menuju Masyarakat Mandiri (Pengembangan Model Sistem Keterjaminan Sosial). Jakarta: Penerbit PT. Gramedia Pustaka Utama.

Anwar, Manajemen Pemberdayaan Perempuan, Bandung: Alfabeta, 2007 Ratih

Dewayanti, dkk, Marjinalisasi dan Eksploitas Perempuan Usaha Mikro di Perdesaan Jawa, Bandung: AKATIGA, 2004

Tajudin Noor Efendi, Sumber Daya Manusia dan Peluang Kerja dan Kemiskinan, Yogyakarta: Tiara Wacana, 1995

Sutoro Eko, Pemberdayaan Kaum Marjinal, Yogyakarta: APMD Press, 2005 